\title{
大阪湾の物質循環管理に向けた 陸域負荷の人為的制御に関する数值実験 \\ NUMERICAL EXPERIMENTS IN ARTIFICIAL CONTROL OF INFLOW LOAD AIMED AT MATERIAL CYCLE MANAGEMENT IN OSAKA BAY
}

\author{
中谷祐介 1 ・川住亮太 $2 \cdot$ 西田修三 3 \\ Yusuke NAKATANI, Ryota KAWASUMI and Shuzo NISHIDA \\ 1 学生会員 修 (工) 大阪大学大学院 工学研究科地球総合工学専攻（†565-0871 吹田市山田丘2-1)
2 学生会員 学 (工) 大阪大学大学院 工学研究科地球総合工学専攻（†565-0871 吹田市山田丘2-1）
3 正会員 工博 大阪大学大学院教授 工学研究科地球総合工学専攻（†565-0871 吹田市山田丘2-1）
}

In Osaka Bay, eutrophication phenomena occur in the bay head while nutrient concentrations are decreasing in the western part of the bay. In this study, we conduct numerical experiments in artificial control of inflow load to manage material circulation in the bay. The simulation results indicated that the future improvement of treated water quality would not contribute to resolution of organic pollution and might change nutrient balance in the eastern part of the bay. It would also be difficult to increase artificially the primary productivity in the western part of the bay due to the limitation of nutrient load potential from land and strong tidal mixing.

Key Words : Osaka Bay, nutrient, water quality, inflow load, numerical simulation, material circulation control, treated water

\section{1. はじめに}

30年以上にわたる陸域負荷削減施策は閉鎖性海域の有 機污濁と富栄養の改善に大きく寄与し，大阪湾は一時期 の危機的な状態から脱することに成功した. しかし，一 方的な負荷削減は海域への流入負荷を減少させただけで なく, その質も大きく変化させ, 海域の栄養塩バランス の変質を引き起こした1). 図-1に示すように, 大阪湾で は湾奥部海域は今なお富栄養状態にある一方で，湾西部 海域では栄養塩が枯渇しつつある．また，大阪湾に隣接

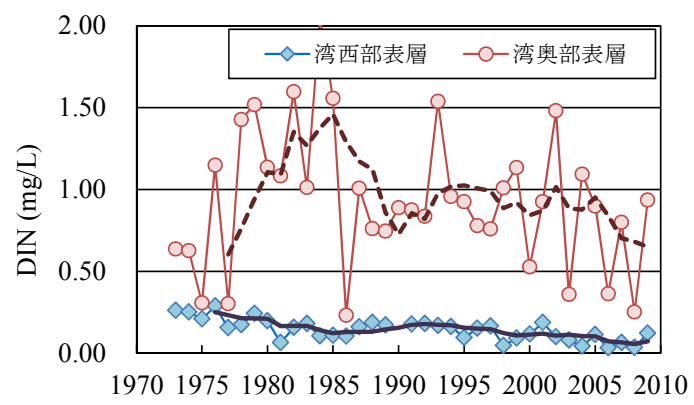

図-1 大阪湾における冬季の表層DIN濃度の変遷 （浅海定線水質調査より作成. 太線は5年移動平均値.）
する播磨灘では負荷削減の結果，近年は貧栄養状態にあ り, 冬季には大型珪藻の出現によるノリの色落ち被害が 生じている2)。これらの事象は，閉鎖性海域における富 栄養状態の解消と生産性の維持の両立が容易ではないこ とを示唆している. 特に，大阪湾では湾内の環境勾配が 大きく物質循環が円滑でないために, 従来の単純な量的 規制だけでは海域環境の健全化は困難と考えられる.

一方，大阪湾流域圈では，高度経済成長期以降に総量 規制や下水道施設の整備が進められ，その水・物質循環 には自然循環系だけでなく人工循環系が大きな影響を及 ぼすようになってきだ). 今後, 劣化した海域環境の再 生に向けた物質循環の管理方策の一つとして，人工循環 系を利用した陸域負荷の人為的制御が挙げられる. 例え ば，下水放流水に含まれる栄養塩の量や質を適切に制御 することで, 海域の栄養塩環境をコントロールできる可 能性が期待できる. しかし, 具体的な方策を提案するた めには, 陸域負荷の実態と海域の物質輸送場を精確に把 握し，方策の実効性を定量的に予測する必要がある.

本研究では，まず，統計資料の収集と分析により，大 阪湾に流入する陸域負荷の実態とその空間分布を明らか にする. 次に，三次元数值シミュレーションにより海域 の流動・水質場を再現するとともに, 海域の物質循環管 
理に向けた陸域負荷の人為的制御策を提案し，その効果 を検証する．なお，大阪湾の物質循環には底泥や外洋を 起源とする栄養塩の動態も無視できないことが指摘され ているが，今回は陸域負荷の変化に対する湾内水質の応 答性を捉えるために，底泥や外洋から供給される栄養塩 量の変動が比較的小さい冬季を対象に解析を行う。

\section{2. 対象領域の概要}

図-2に大阪湾の地形と, 流入する河川および下水処理 場の分布を示寸. 大阪湾は水面面積約 $1,447 \mathrm{~km}^{2}$, 湾容積 約440億 $\mathrm{m}^{3}$ の内湾である. 湾東部では水深が $20 \mathrm{~m}$ 以下と 比較的浅く, 湾口部に向かうにつれて深くなっている. 湾奥部では主要河川が集中しているため, 一年を通じて 成層している一方で，湾西部は海峡部の強混合によって 冬季には鉛直方向にほぼ一様化している.

集水面積は約 $10,140 \mathrm{~km}^{2}$ と大きく, 大阪や京都といっ た多くの大都市を抱えている. 2007年度末時点において， 大阪湾流域には105箇所の下水処理場が立地しており， そのうち55箇所では高度処理が導入されている. 特に, 大阪市内河川・寝屋川流域と神崎川流域には大規模な処 理場が多数立地しており, 流域における主要な負荷供給 源となっている. また，神戸港から阪南港にかけては， 海域に直接放流する大規模事業場や下水処理場が点在し ている．地域別の漁獲高は神戸，淡路島，泉州地域で大 きく, また, 神戸市のポートアイランド以西と淡路島の 沿岸部ではノリの養殖が行われている.

\section{3. 方法}

\section{（1）陸域負荷の算定方法}

海域の物質循環を正しく解析するためには，陸域負荷 条件を精確に与える必要がある，従来，陸域負荷はCOD， T-N，T-Pを指標とした見積もりはなされてきたものの， 物質循環解析に重要な栄養塩の形態別算定はなされてこ なかった，筆者らはこれまでに，出水時を含めた現地調 查や各種排水に関する統計資料の収集・分析を行うこと により，大阪湾へ流入する陸域負荷について詳細な算定 を図ってきた．算定方法の詳細は前報1,4) に譲ることとし， ここでは概要のみを示す。

算定期間は2008年冬季とし，対象とする水質項目は CODおよび形態別栄養塩 $\left(\mathrm{NH}_{4}-\mathrm{N}, \mathrm{NO}_{2}-\mathrm{N}, \quad \mathrm{NO}_{3}-\mathrm{N}, \mathrm{O}-\right.$ $\left.\mathrm{N}, \mathrm{PO}_{4}-\mathrm{P}, \mathrm{O}-\mathrm{P}\right)$ である. 主要河川である淀川，大和川 については，一時間ごとの水位モニタリング值と H-Q式 から流量を求め, 平水流量を閾值に低流量時には平水時 水質濃度を, 高流量時にはL-Q式)を適用して負荷量を 算定した. また，解析期間には大規模な降雨がなかった ため, 流量が比較的少ないその他中小河川からの流入負

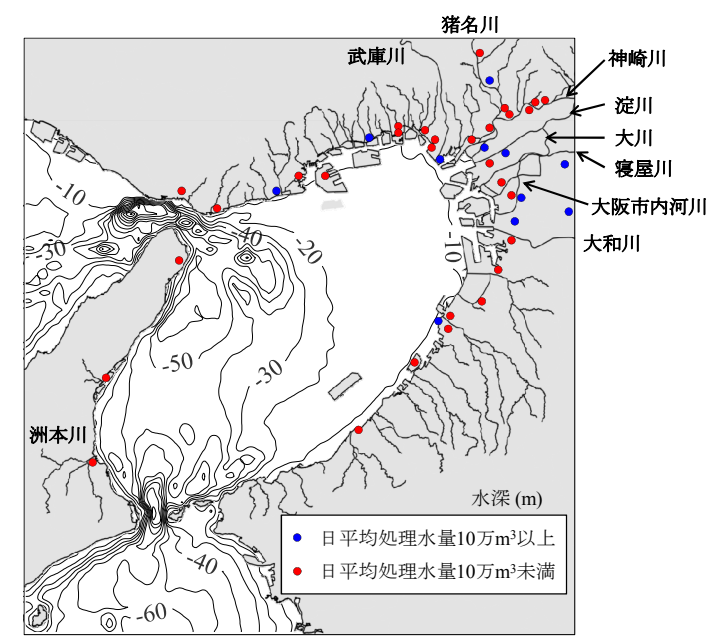

図-2 大阪湾の地形と，流入河川および下流部に位置する 下水処理場の分布

荷については, 出水に伴う変動を無視しても算定結果に 大きな誤差が生じないと判断し, 年平均流量および平水 時水質濃度（ともに前後年度含む3年平均值）を用いて 算定した. 下水処理場からの放流負荷量については，下 水道統計および各処理場発刊の水質管理年報を基に, 解 析期間における実績負荷量を各処理場について個別に求 めた．その他に，流域下流部に位置する事業場および浄 化槽等功の負荷量も算定するとともに, 取水・導水に 伴う負荷量の受け渡しも考慮した．陸域負荷の空間分布 を算定する際には，大阪湾流域を7つ（淀川流域, 大和 川流域，神崎川流域，大阪市内河川・寝屋川流域，泉州 地域，神戸地域，淡路地域）に区分して扱った.

\section{（2）数值モデルの概要}

流動計算には三次元モデルECOMSED ${ }^{5)}$ 用いた．本 モデルはPOMをべースに開発され，土砂輸送や風波等 のモジュールが付加されている. 水平および鉛直方向の 渦動粘性・拡散係数はそれぞれSmagorinskyモデル（定 数值0.2), Mellor-Yamadaモデル（背景值2.0× $10^{-5} \mathrm{~m}^{2} / \mathrm{s}$ ) により算定した.

水 - 底質場はRCA ${ }^{6}$ モデルを用いて計算した. モデル 内で考慮している物質循環過程の概要を図-3に示寸．酸 素O, 炭素C, 窒素 $\mathrm{N}$, リン $\mathrm{P}$, 珪素 $\mathrm{Si}$ を指標元素として 計24個の状態変数を考慮した. 本解析では冬季珪藻類, 冬季非珪藻類, 夏季珪藻類の 3 種類の植物プランクトン を設定し, 光合成時の栄養塩の取込量は周囲水の栄養塩 濃度に依存して変化するようにモデル化している．有機 態成分は懸濁態成分と溶存態成分に区別され，さらにそ れぞれ易分解成分と難分解成分に分けて扱われている. また，底質モデルは好気層と嫌気層の2層で構成され， 有機態C，N，Pは分解速度に応じてそれぞれ3画分が考 慮されている. 水質, 底質に関する各種パラメータは, 既往研究による採用值を基に，観測結果をよく再現する ように調整して決定した. 


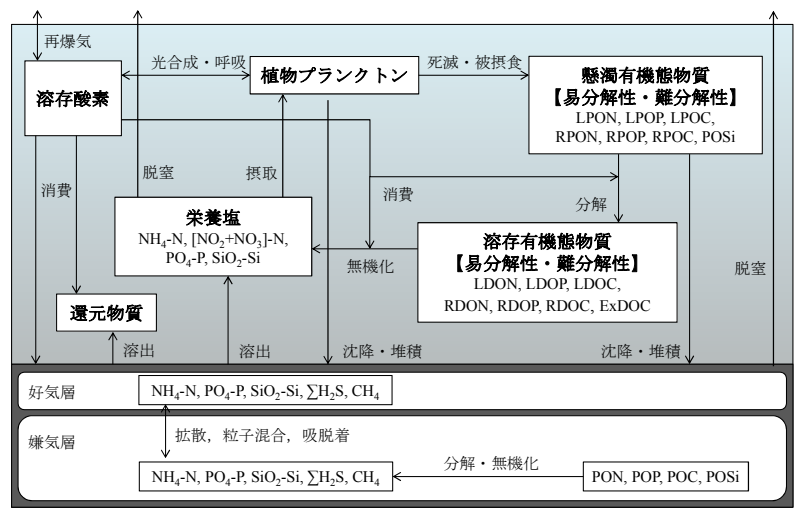

図-3 水 - 底質モデルの構成

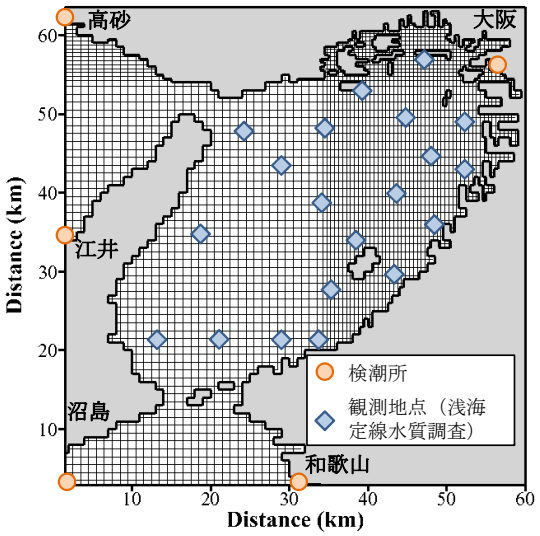

図-4 計算領域

\section{（3）計算条件}

湾全体における物質循環を解析するため，計算領域は 図-4に示寸範囲に設定した。図には計算条件や再現性の 検証に用いる検潮所と水質調査地点（浅海定線水質調 査）の位置もあわせて載せている．水平方向にはデカル

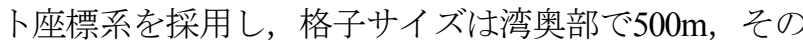
他で $1 \mathrm{~km}$ とした．鉛直方向には等間隔20層のの座標系を 採用した。助走計算を1ヶ月間行った後，2008年2月の 1ケ月間を解析期間とした．差分時間は流動計算につい ては8sec，水質計算については180sec とした。初期塩 分・水温には1月の平均的な值 (塩分 32.5 , 水温 $12.5^{\circ} \mathrm{C}$ ) を湾内で一様に与え，静止状態から開始した。

開境界には検潮所（高砂，江井，沼島，和歌山）にお ける実測潮位（T.P.基準）を与え，その間は線形に補間 した．水温，塩分，水質濃度は浅海定線水質調査結果を 基に，境界に最も近い調查地点の值を一定に与えた。 気 象条件には，11箇所の測候所における毎時観測值の平均 を与えた．ただし，風場については空間分布を考慮する ために，まず，各測候所の観測值について $1 / 7$ 乗対数則 を用いて $100 \mathrm{~m}$ 高度風速を求め, Kriging法により面デー 夕に補間した後，再び $1 / 7$ 乗則によって海面上 $10 \mathrm{~m}$ の風場 を推定した。なお，陸上観測值には海上風速補正（1.5 倍）を施した.
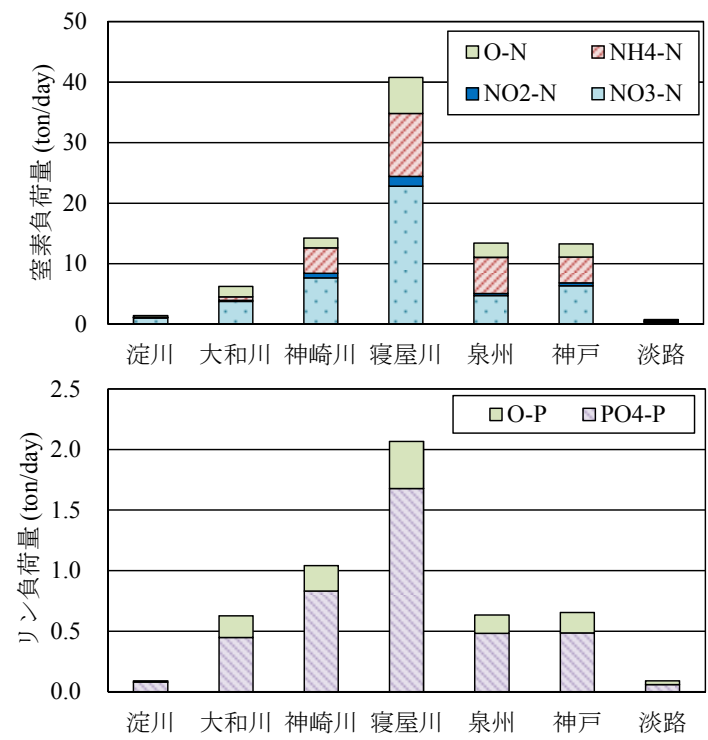

図-5 陸域負荷の空間分布

\section{4. 結果}

\section{（1）陸域負荷の算定結果}

大阪湾に流入する陸域負荷の空間分布を図-5に示寸. なお，最大の流入河川である淀川では，枚方大橋より下 流部において約 $45 \mathrm{~m}^{3} / \mathrm{sec}$ が導水または取水され，さらに 淀川大堰直上において大川を介して大阪市内河川 40〜 $120 \mathrm{~m}^{3} / \mathrm{sec}$ 環境維持を目的に導水されている. そのため, 本川河口からはほとんど流出がなく，大半は大阪市内河 川を通じて大阪港内に流出している．図-5に示している

「淀川」とは本川河口から流出する分であり，大川への 導水分は「（大阪市内河川・）寝屋川」に含まれている ことに注意されたい.

算定期間における大阪湾への総陸域負荷量はCOD，TN，T-Pのそれぞれについて116ton/day，89.9ton/day， 5.20ton/dayであった. いずれも大阪市内河川・寝屋川流 域からの負荷が大きく，大阪湾一の総陸域負荷量のうち， それぞれ約 $46 \% ， 45 \% ， 40 \%$ を占めている，当流域では 13箇所の下水処理場が供用されており，大阪湾への総陸 域負荷量のうちCOD，T-N，T-Pのそれぞれ約 $21 \% ， 33 \%$, $24 \%$ が当流域内の下水処理場に由来している.また，総 陸域負荷の $/ \mathrm{P}$ 比（本論文ではDIN/PO $/ \mathrm{PO}_{4} \mathrm{P}$ モ比のことを 指す）は41.3，特に下水処理場負荷の $\mathrm{N} / \mathrm{P}$ 比は47.0 と Redfield比より高い值を示した.

\section{（2）モデルの再現性}

大阪港潮位について，計算値と観測值の比較を図-6に 示す，振幅，平均潮位，位相のいずれについても，計算 值は観測值とよく一致している. 図-7に塩分，水温, DIN， $\mathrm{PO}_{4}-\mathrm{P} ， \mathrm{Chl} .-\mathrm{a} ， \mathrm{~N} / \mathrm{P}$ 比の表層分布について，計算 結果（2月 5日 13:00瞬間值）と観測結果（2月4～6日の日 


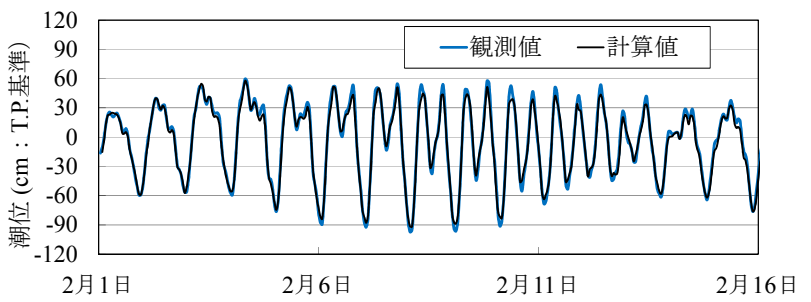

図-6 大阪港における潮位変動

中調査）を示寸．塩分は河川が集中している湾奥部から 湾口部にかけて勾配がみられる. 水温は神戸港沖で極小 を示し，紀淡海峡に向かうにつれて高くなっている，計 算結果では，湾奥部において塩分，水温がともに若干低 くなっているが，いずれも特徵的な分布パターンはよく 再現されている．湾東部の成層海域では冬季にも拘わら ず活発な一次生産が生じており, その結果リンが枯渇し ている．一方，湾央部では播磨灘から低栄養塩濃度の海 水が流入するとともに，一次生産に利用されることで DINが低い值を示している。概ね潮汐フロントを境にし て，東側ではリン制限，西側では窒素制限が働いている。 湾南西部では紀伊水道を通じた外洋水の流入により, 高 塩分值を示寸とともにChl.-aは低い值を示している. N/P 比は湾奥部で観測值に比べて低い值となっているものの, Redfield比を示すラインはほぼ一致しており, 計算結果 は海域の栄養塩バランスや一次生産の制限構造を良好に 再現しているといえる.

\section{（3）大阪湾における物質輸送場}

2月1～15日における残差流系と密度の期間平均值につ いて，表層分布の計算結果を図-8に示寸，明石海峡と紀 淡海峡の前面では全層にわたって時計回りの潮汐残差流 （それぞれ沖ノ瀬環流，友ヶ島反流と呼ばれる）が，ま た，湾奥部中層には高気圧性循環が形成されており，既 往研究》によって指摘されている大阪湾特有の残差流系 が再現されている，湾奥部表層に流入した河川水は阪南 港付近まで南下した後, その一部は潮汐フロントに沿つ て北上し, 神戸港沖から明石海峡へ向かって西進してい る. しかし，栄養塩やChl.-aの分布から推察できるよう に, 湾奥部に注ぐ主要河川を起源と寸る栄養塩は河口沖 において速やかに一次生産に利用され, 粒子態となって 下層一沈降するために，湾西部へはほとんど輸送されて いないと推察される.

\section{5. 物質循環の管理方策の検討}

\section{（1）方策シナリオの構築}

前章で得られた陸域負荷と物質輸送場の情報を基に, 陸域負荷の人為的制御による物質循環の管理方策シナリ オを構築し，その効果を数值実験によって検証する. 現 在，大阪湾では湾東部における慢性的な有機污濁と，湾
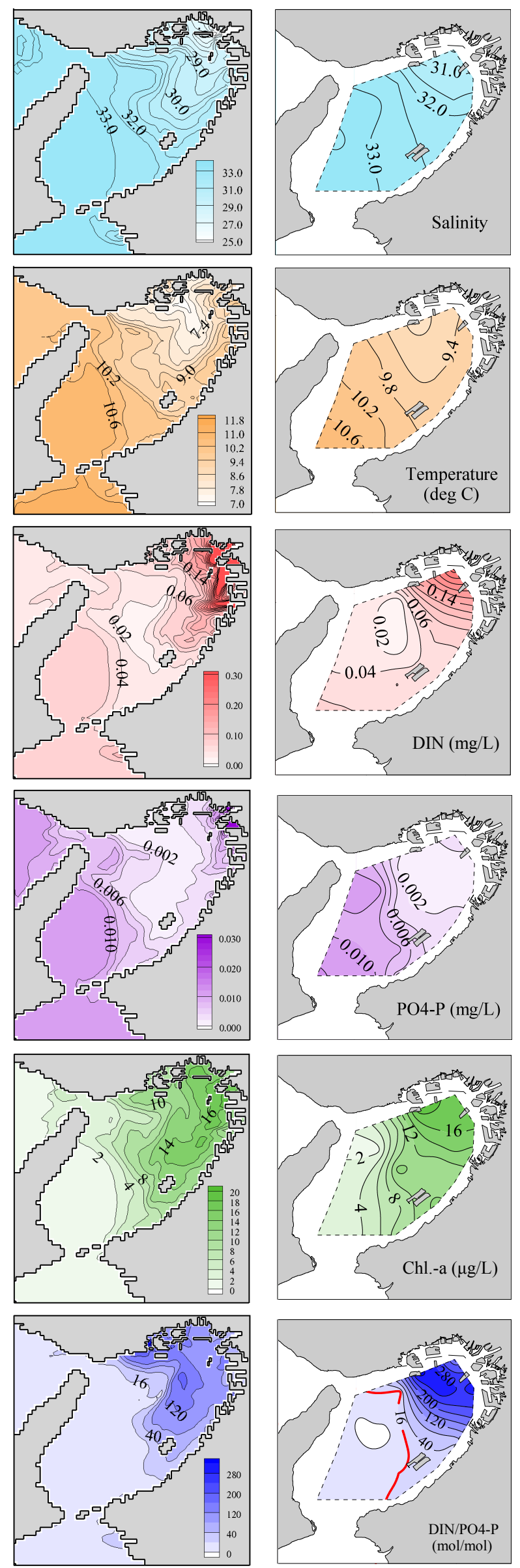

図-7 表層水質分布（左 : 計算結果, 右 : 観測結果) 


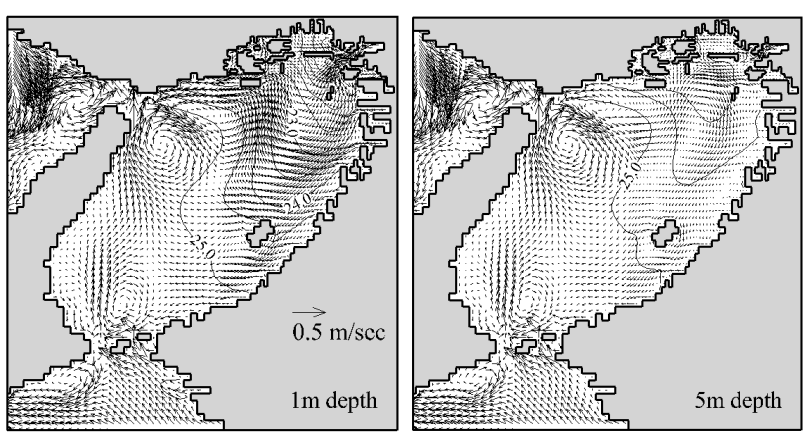

図-8 残差流系と密度 $\sigma \mathrm{t}$ の水平分布

西部の低栄養塩環境における基礎生産力の低下が問題と なっている. そこで本研究では, この二点の改善を目的 とした方策とその効果について検討する.

\section{a）シナリオA : 【湾東部における有機污濁の改善】}

現在，大阪湾流域では大阪湾流域別下水道整備総合計 画が実施段階にあり，2004年度時点で高度処理を実施し ている処理場における実績平均処理レベルを基に，2025 年度を目標年次に放流水質の目標值が設定されている. ここでは，整備目標が達成された場合を想定し，今後の 下水道整備に対寸る海域水質の応答性を解析寸る.

なお，窒素については下水処理過程における除去能力 がCODやリンに比べて従来低い水準にあったが，大阪湾 流域では高度処理技術の普及が近年進められており，窒 素についても除去能力が着実に向上しつつある. そのた め, CODやリンについては今後下水道整備による大きな 負荷削減は期待できないものの，窒素についてはさらな る削減の余地があり, 陸域負荷のN/P比は低下していく ものと予想される，上述の算定方法により，仮に目標が 達成された場合の陸域負荷量を試算すると，COD，T-N, T-Pの総陸域負荷量はそれぞれ101ton/day，68.5ton/day，

4.67ton/dayとなり，2008年冬季負荷量に対してさらに 13\%，24\%，10\%の削減がそれぞれ見込まれ，その結果， N/P比は34.6にまで低下寸る.

b）シナリオ $\mathrm{B}$ ：【湾西部における基礎生産力の向上】

湾奥部に流入した栄養塩は成層海域内で一次生産に利 用されるために，湾西部には輸送されにくい，そのため， 湾西部の基礎生産力を高めるためには，湾西部へ直接流 入する負荷を増加させることが有効と考えられる.

淡路島から神戸港以西の沿岸では，2007年度末時点に おいて6箇所の下水処理場が処理水を大阪湾に直接放流 している. 2008年冬季の実績值を基に計算すると，これ ら処理場における窒素除去率（=除去量/処理場への下水 流入負荷量）は46〜91\%の間にあり，加重平均で53\%で あった. 今回は比較的現実的なモデルケースとして，管 理運転により窒素除去率を20\%にまで一律に低下させた 場合の海域水質の応答性を解析する。この方策により大 阪湾へのT-N負荷量は92.3ton/yearとなり，2008年冬季負 荷量に対して約 $2.6 \%$ の増加が見込まれる.
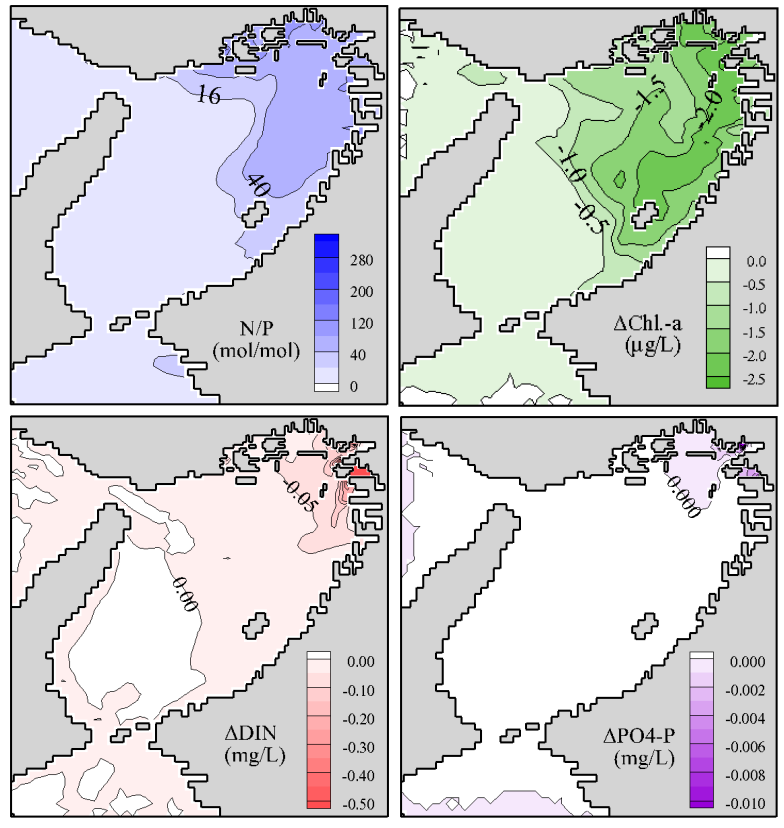

図-9 シナリオAの解析結果

\section{(2) 解析結果}

a）シナリオA

図-9に方策後の $\mathrm{N} / \mathrm{P}$ 比と, 各表層濃度の変化量（方策 後一方策前）を示す．湾東部ではChl.-a濃度が低下して いるがその変化は約 $2.0 \mu \mathrm{g} / \mathrm{L}$ 上さく, 高度処理技術の普 及は有機污濁の改善にはあまり寄与しない結果が得られ た. これは湾東部表層における一次生産の大半が再生産 であるためと考えられる，栄養塩に注目寸ると，方策に より陸域負荷のN/P比は低下寸るが, 湾東部では依然と してリン制限が働いている，そのため，湾東部では $\mathrm{PO}_{4}$ P濃度にはほとんど変化が認められないが，DIN濃度は 陸域負荷量の減少に伴って低下し, その結果N/P比も小 さくなっている.

さらに，COD，窒素，リンのそれぞれの削減に対する 湾東部表層水質（塩分32以下を示寸範囲の平均值）の応 答性を解析したところ, 図-10に示すようにTOC濃度は いずれもほとんど変化しない一方で，N/P比は大きく変 動する結果が得られた．これは，陸域負荷の一方的な人 為的削減が海域の栄養塩バランスを大きく変化させる可 能性を示唆している. N/P比の変化が海域環境に及ぼす 具体的な影響は不明であるが，優占プランクトン種の変 化など生態系を変質させる可能性も否定できず，陸域負 荷については量だけでなく質の管理も今後は必要と考え られる，今回の解析では観測結果をよく再現するように 各種パラメータを決定した結果, 陸域負荷の変化に依ら ず，冬季珪藻類と冬季非珪藻類がほぼ同じ割合で分布し ていた. しかし, 植物プランクトンの生理特性, 特に栄 養塩の取込比や半飽和定数については依然不明な部分が 多く残されている．物質循環の管理にあたってはこうし た科学的不確実性を考慮とした慎重な検討が必要であり, 今後の重要な課題であると考える. 

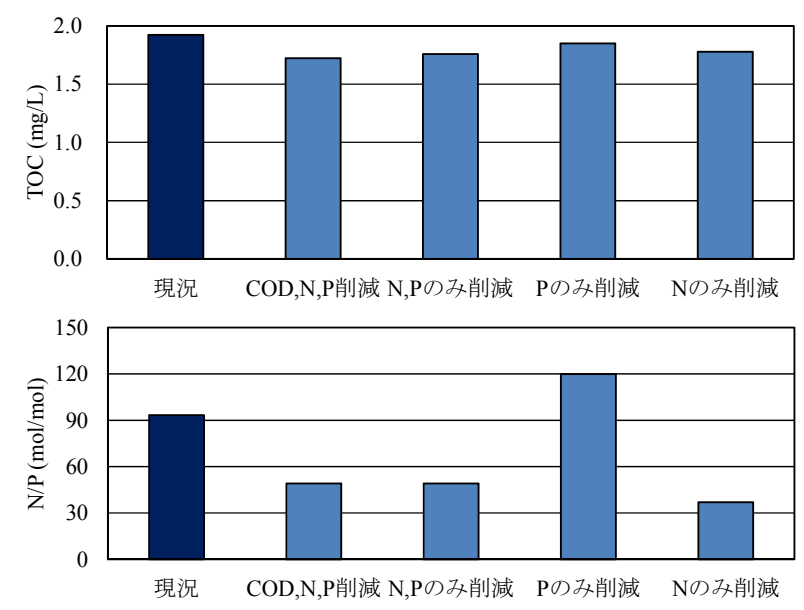

図-10 負荷削減に対する湾東部表層水質の応答性
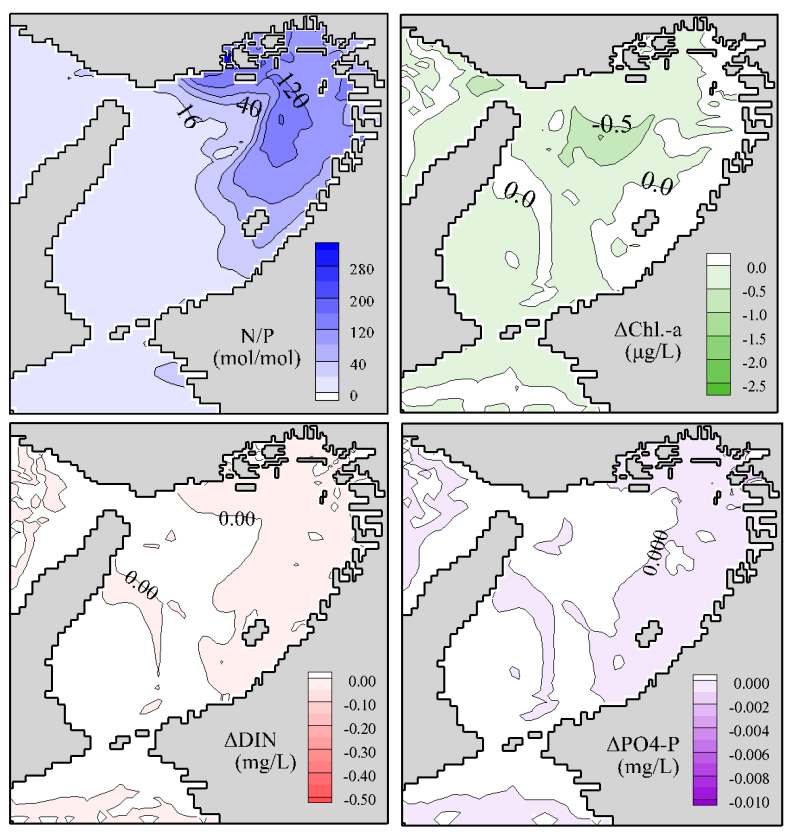

図-11 シナリオBの解析結果

\section{b) シナリオ $\mathrm{B}$}

図-11にシナリオBの解析結果を示す。湾全体におい ていずれの項目についても有意な変化は認められない. これは湾西部沿岸に位置寸る下水処理場での処理水量が 少ないことに加え，沖ノ瀬環流による拡散希釈効果が大 きいためと考えられる．よって，湾西部では人為的な栄 養塩負荷増大によって, 湾スケールの基礎生産力を向上 させることは難しいと考えられる.

また, このような物質輸送構造を踏まえると, 湾西部 において近年みられる栄養塩濃度の低下は，湾奥部一流 入する陸域負荷の減少によるものではなく，隣接する播 磨灘における貧栄養化の影響である可能性が高いと考え られる。

\section{6. おわりに}

本研究では，冬季を対象に大阪湾に流入する陸域負荷 の詳細な算定を行うとともに，負荷の人為的制御に対す る湾内水質の応答解析を行った. 本研究で得られた主な 結論を以下に示す.

（1）2008年冬季おける大阪湾への陸域負荷量はCOD，TN，T-Pについてそれぞれ116ton/day，89.9ton/day， 5.20ton/dayであり，その40～50\%は大阪市内河川を通じ て，大阪港一集中的に負荷されていることがわかった.

(2) 陸域負荷の変化に対寸る湾内水質の応答性について, 三次元数值モデルを用いて解析したところ，今後の下水 道整備は湾東部における有機污濁の改善にはあまり寄与 しない結果が得られた。 また，一方的な負荷削減は，海 域の栄養塩バランスを変化させる可能性が示唆され，今 後さらに慎重な検討が必要と考えられた.

(3) 数值シミュレーションの結果, 神戸港 - 淡路島間に 位置する下水処理場からの窒素負荷の増大は, 湾西部海 域の基礎生産力の向上にほとんど寄与しない結果が得ら れた．湾西部の水質環境には沖ノ瀬環流による拡散希釈 効果が支配的であり，人為的な陸域負荷制御によって湾 スケールの基礎生産力を向上させることは難しいと考え られた。

謝辞 : 本研究を進めるにあたり，関係機関の方々には資 料のご提供等のご高配を受けた。ここに感謝の意を表す るとともに, 本研究の一部は科学研究費補助金（基盤研 究(B) No. 21360236） により行われたことを付記する.

\section{参考文献}

1) 中谷祐介，川住亮太，西田修三 : 大阪湾に流入する陸域負荷 の実態・変遷と海域環境の変化，土木学会論文集B2（海岸 工学) , Vol.67, No.2, pp.886-890, 2011.

2) 多田邦尚, 藤原宗弘, 本城凡夫 : 瀬戸内海の水質環境とノリ 養殖, 分析化学, Vol.59, No.11, pp.945-955, 2010.

3) 西田修三, 前田瑛美, 長澤稔郎, 吉田淳貴 : 淀川流域圈の水 質の変遷と下水道システムの影響解析, 水工学論文集, 第54 巻, pp.1339-1344, 2010.

4) 中谷祐介，西田修三 : 淀川・大和川における出水時負荷特性 之陸域流入負荷の評価, 水工学論文集, 第54巻, pp.16151620, 2010.

5) HydroQual: A Primer for ECOMSED Version 1.3, 2002.

6) HydroQual: User's Guide for RCA (Release 3.0), 2004.

7) 藤原建紀, 肥後竹彦, 高杉由夫 : 大阪湾の恒流と潮流-渦, 海岸工学論文集, 第36巻, pp.209-213，1989.

(2011. 9. 30受付) 